\title{
Chemistry Teaching in Selected Public High Schools in Marawi City: An Assessment
}

\author{
Dayamon T. Magdara
}

\begin{abstract}
A purely qualitative method of research utilizing the questionnaire, document analysis, interviews, and observation were used in the collection of data needed for this investigation. Three public high schools were used as participants with a total of nine teachers and 90 students. Findings showed that no one among the teacher-respondents in the three selected high schools had undergraduate BS/BSE Chemistry degree, neither that finished master's degrees have Chemistry as their field of specialization. Majority however, have chemistry units earned at the baccalaureate and graduate levels. Teacher-respondents perceived that they are "well-qualified" to teach simple chemistry concepts which usually consist of the introductory portion of the text. Fortyfour percent of the respondents felt that they are "not well qualified" to teach many concepts and principles in Chemistry that are found in the middle and towards the end of chemistry textbooks. Only very few were given the opportunity to participate in-service training programs. Majority also adhered to the use of lecture-chalk-talk approach in teaching. They also viewed teaching as a way of changing students' behavior and learning through construction of meanings. Facilities and support resources for teaching are very minimal if not none at all. Respondents are suggesting that there is a need to upgrade academic capabilities of teachers and that they should employ varied teaching strategies
\end{abstract}

Index Terms-Chemistry teaching, public high schools, Marawi City, assessment.

\section{INTRODUCTION}

There is an urgent call for the Philippines to develop a culture of science if it has to be able to keep up with the rapid advances in science and technology in the world today. But in order to successfully meet this challenge, educational institutions all over the country should become more innovative and creative in developing new science courses that are relevant and will have practical applications in today's highly globalized society. Science educators, therefore, must participate in exploring the many possibilities by which science instruction can be improved for they are the ones tasked to bring science education to a cutting edge [1].

Admittedly, the benefit of science can be seen in one's daily life - practically everything that an individual uses and consumes traces science as its source - man's inventiveness, creativity, ingenuity, and innovativeness, translated into a variety of inventions and products as well as services that have made modern life comfortable for many. In the Philippines, the state recognizes the importance of science and technology for national development and progress. Thus the 1987 Philippine Constitution provides that:

Manuscript received September 28, 2013; revised November 28, 2013.

Dayamon T. Magdara is with the Mindanao State University, Philippines (e-mail: anabelievillavaldez@gmail.com).
"The state shall give priority to research and development, invention, innovation and their utilization; and to science and technology education, training and services. It shall support indigenous, appropriate and self-reliant scientific and technological capabilities, and their application to the country's productive systems and national life [2]."

Chemistry is considered as one of the cornerstones of science, technology and industry. It forms the foundation of the life sciences and the core of every technology that people enjoy today. The chemical sciences provide enabling infrastructures that deliver foods, fuels, medicine and materials that are part of everyday life. Moreover, the contribution of chemists and chemical engineers are central to the technological progress of many areas including the chemical, pharmaceutical, electronics, agriculture, automobile, and aerospace industries. These contributions have created new jobs and boost the country's economic growth. In addition, the contributions of chemistry to public health through such things as new biomaterials, drug design, and drug delivery technology and gene therapy have led to the improvement of health and the attainment of longer life. In short, chemistry contributes in critical ways to the economic strength, security and well-being of the nation [3].

In this context, we need to have an excellent science and technology education particularly chemistry education in order for us to live and participate in a world that is increasingly becoming more science and technology oriented. This can only be done by teaching chemistry with utmost competence to enhance student's capabilities [4]. In doing so, they will learn to appreciate the fact that chemistry is not only useful and relevant but interesting and productive as well [5]. There is a need therefore to assess the status of chemistry education at the basic level because every child has the right to quality education as mandated by the constitution. In addition, the government hopes to become a newly industrialized country which can only be attained through quality science and technology education for the Filipino youth.

\section{Methodology}

\section{A. Method of Research Used}

A purely qualitative method of research utilizing the questionnaire, document analysis and interview in collecting data was used in this study. According to Fraenkel and Wallen (2003), qualitative research method is used to obtain an in-depth look at particular individual, situation or set of materials. Since the researcher wanted to obtain a holistic or complete picture of what goes on in chemistry classrooms, the qualitative method of research was the most appropriate to address the research questions and fulfill the purpose of the 
study.

\section{B. The Setting}

The study was conducted in three big public high schools in Marawi City. Marawi City was formerly known as Dansalan, the capital of Lanao del Sur. It is located in the Central Mindanao. A great majority of populace are the Muslims called Maranaos. Marawi City covers a total area of 5,838 hectares with an elevation of 2,350 feet (Census Statistics 2000). It is bounded by the Municipality of Kapai in the north, the Municipality of Bubong in the east, the Municipality of Marantao in the west, and by the beautiful and enchanting Lake Lanao in the south.

\section{The Sample Schools}

Three public high schools in Marawi City namely: the Marawi City National High School (MCNHS), the MSU Lanao National College of Arts and Trade (LNCAT) and the MSU-University Training Center (MSU-UTC) were selected by the researcher as respondent schools in the study. They were considered because these schools are just few meters away from each other and thus, it is convenient for the researcher to gather data. Moreover, these schools have the biggest student population in the area.

Fig. 1 show the size of the student population and the number of teachers in the different sample schools. These schools are following the Department of Education, Science and Technology (III) Curriculum.

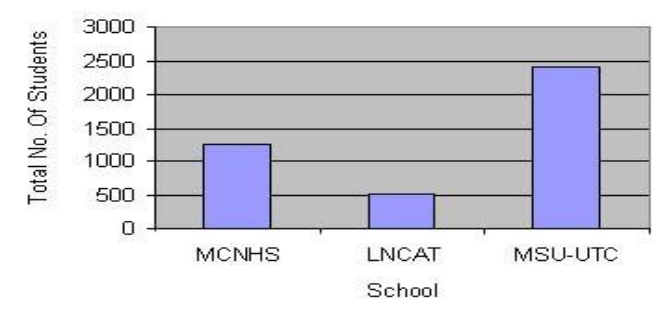

Fig. 1. Students population in the three sample schools.

\section{RESULTS}

The study sought to answer the following questions.

- How qualified are the teachers handling chemistry course in selected public high schools of Marawi City?

- What methods and strategies are used by the teachers in teaching Chemistry? Are these strategies in consonance with the ones suggested by the Basic Education Curriculum of the Department of Education?

- What are the teaching practices of chemistry teachers in the selected public high schools in Marawi City?

- What learning environments are provided by chemistry teachers for their students?

- What are the chemistry teachers' views about teaching and learning? Are they congruent with the accepted views about teaching and learning or how science should be taught?

- How adequate are the laboratory facilities for teaching chemistry?

- What problems are encountered by the teachers and students in teaching and learning Chemistry?

- What suggestions are offered by the teachers and students to improve the teaching and learning of Chemistry?
Using qualitative method of research utilizing the questionnaire, observation, document analysis and interview in collecting data, the following findings were obtained:

\section{A. Chemistry Teacher Educational Qualification}

The ages of the respondent ranged from 20 to 52 for the teacher-respondents and 14 to 17 for the student-respondents.

Nobody had undergraduate preparation of BS-Chemistry or BSE major in Chemistry except B.S. chemical engineering.

Two of teachers graduated with (BSE) degree, one finished Bachelor of Arts in Anthropology (A.B.). Three of them took BS biology and two were graduate of BS Chemical Engineering

Six teachers have earned units leading to Master of Arts degree but they have not completed academic requirements. Only two teachers have earned a master's degree. Their field of specialization however is not chemistry but general science.

\section{B. Content Preparedness}

Based on the total chemistry units earned both in undergraduates and graduate level, only two of teacher had earned 32 units in chemistry. Six teachers had earned chemistry units ranging from 15-24 units. Two teachers had not earned any chemistry units at all.

Chemistry teachers' rating of their preparedness to teach chemistry teachers are "very well qualified" to teach some chemistry topics like symbols of element, importance of chemistry to daily life and etc. Forty-four percent felt "not well qualified" to teach the following topics like "Heat and Chemical Reactions" and others. However there are a lot of topics that many teachers felt well qualified in teaching topics like writing Chemical Formulas and others.

\section{Professional Development of Chemistry Teachers}

Four teacher respondents had attended the (RSTC) summer training. Only one teacher has attended the SMEMDP training, five of the respondents had attended the RISE training. Nobody from these 9 respondents had attended the PASMEP training and the DECS-ISP training and PROBE.

\section{Chemistry Teachers' Teaching Strategies}

All the chemistry teachers always used the lecture method. Question and answer usually follows the lecture method. Practical work, Group discussion, Making projects and other teaching strategies were seldom used by the chemistry teacher.

\section{E. Topics Covered by the Chemistry Teacher}

Some of the topics in chemistry have not been covered by the chemistry teachers like Chemical Reactions, Heat of Reaction, Colligative Properties of Solution and Uses of Radioactive Element and others.

\section{F. Teaching Practices of Chemistry Teachers}

The most common practices of the teacher were: roll call before starting the lecture, brief review of the past lesson, lecture proper before discussion and quizzes as well as assignment. 


\section{G. Teachers' Views about Learning}

Students will learn if they are interested. Learning takes place if there is a change in the behavior of the learner. Learning is construction of meaning

\section{H. Teachers' Views about Teaching}

The discovery method. Teaching by using a variety of teaching materials. Teaching is effective if the teacher uses the "hands-on" approach

\section{Learning Facilities and Resources}

The three schools lack the laboratory facilities and other resources.

\section{J. Problems Encountered by Chemistry Teachers and Students}

The schools lack laboratory materials and facilities. Inadequate textbooks and facilities. Teacher's lack of mastery in the subject. Students lack Mathematics and English proficiency.

\section{K. Students' Suggestion to Improve Chemistry Teaching and Learning}

Upgrading of the chemistry teachers' academic capabilities, Teachers should employ a repertoire of teaching strategies. Teachers should provide stimulating and encouraging classroom environment that is conducive to learning. The school should initiate the acquisition of necessary books, laboratory apparatuses and other laboratory equipment and materials.

\section{Teachers' Suggestions to Improve Chemistry Teaching}

Teachers in Chemistry must have a mastery of the lesson. Teachers in Chemistry should give laboratory activities / practical works. Provide students with their own textbooks. Teachers should use visual aids in presenting the topics.

\section{RECOMMENDATIONS}

The policy of hiring chemistry teachers must be strictly enforced. Only those with appropriate chemistry background should be assigned to teach Chemistry.

Competence of chemistry teachers should be upgraded and enriched through relevant continuing education program that will address their needs and inadequacies.
In-service training through seminars, workshops should be conducted periodically to enhance the teachers' subject matter content competencies to be handled by competent resource person.

Every public school should provide for hands-on science learning experiences by ensuring the availability of basic equipment and laboratory facilities and encouraging improvisation as a school project.

Financial assistance should be given priority to chemistry teachers who are willing to pursue further studies in the field of chemistry.

Provide the students with their own textbooks on a rental basis from the school.

The library must always be available and provides new books especially in the sciences.

\section{REFERENCES}

[1] H. C. Gregorio, Principles and Methods of Teaching, revised edition, Quezon City: R.P Garcia Publishing Co., 1976.

[2] H. C. Gregorio and C. M. Gregorio, Introduction to Education in Philippine Setting, Quezon City: R.P. Garcia Publishing Co., 1976.

[3] D. W. Johnson and F. Johnson, "Cycles of learning: cooperation in the classroom," Alexandria, Va: Association for Supervision and Curriculum Development, 1998.

[4] A. S. Lardizabal, Foundation of Education, Psychological, Physiological, Revised Edition, Quezon City Rex Bookstore, 1988.

[5] G. Rhodes and T. Bellamy. (1999). Journal of Teacher Education. [Online]. 50. Available: http://www.questia.com

[6] D. Tiene and A. Engram, Exploring Current Issues in Educational Technology, New York, Mcgraw-Hill Publication Co., 2001.

[7] R. L. Gough and A. K. Griffiths, Science for Life, Harcourt Brace 7 Co. NINSMID (2001), 100 years of Science and Math education in the Philippines, Diliman Quezon City, 1993.

[8] J. Calderon and Gonzales, Methods of Research and Thesis Writing. Phil., National Book Store, Inc., 1993.

[9] EDCOM, Making Education Work, Congress of the Philippines, Quezon City, 1991.

[10] H. M. Mariola, The Students' Performance in Chemistry Problem Solving, unpublished thesis, Mindanao State University, Marawi City, Philippines, 1995.

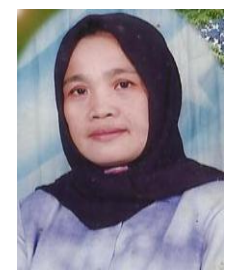

Dayamun T. Magdara is a native in Marawi Lanao del Sur. She finished Ph.D. in science education Biology, MST in General Science at Mindanao State University. She finished BSeD Biology at Mindanao State University -Iligan Institute of Technology Iligan City. She is a permanent faculty in Mindanao State University Marawi City Philippines. Research interest is in science education. She recently participated and Indonesia last July $13-14,2013$ 